E-ISSN: $2502-6674$

P-ISSN: 2502-6666

http://ojs.uho.ac.id/index.php/p_sejarah_uho

\title{
PENERAPAN MODEL PEMBELAJARAN NUMBERED HEAD TOGETHER DALAM UPAYA MENINGKATKAN HASIL BELAJAR IPS SISWA KELAS VII MTS.S ASH-SHIDDIQ TIKEP ${ }^{1}$
}

\author{
ASHAR $^{2}$ \\ e-mail: ashar@yahoo.com \\ H. Anwar \\ e-mail: anwar@uho.ac.id
}

\section{${ }^{1)}$ Hasil Penelitian Tahun $2018,{ }^{2)}$ Alumni Jurusan Pendidikan Sejarah, ${ }^{3)}$ Dosen FKIP UHO}

ABSTRAK: Tujuan utama dalam penelitian adalah 1) untuk meningkatkan aktivitas belajar siswa pada penerapan model Numbered Head Together dalam pembelajaran IPS Siswa Kelas VII MTs.S Ash-Shiddiq Tikep, 2) untuk meningkatkan keefektifan mengajar guru pada penerapan model Numbered Head Together dalam pembelajaran IPS Siswa Kelas VII MTs.S Ash-Shiddiq Tikep, 3) untuk meningkatkan hasil belajar siswa melalui penerapan model Numbered Head Together pada pembelajaran IPS Siswa Kelas VII MTs.S Ash-Shiddiq Tikep. Jenis penelitian ini adalah Penelitian Tindakan Kelas. Penelitian ini dilaksanakan pada tanggal 22 Maret sampai dengan tanggal 26 April 2018 yang dilihat sebanyak dua siklus dan setiap siklus terdiri dari dua kali pertemuan yang dilaksanakan pada semester genap tahun ajaran 2017/2018 pada siswa kelas VII MTs.S AshShiddiq Tikep. Prosedur penelitian ini meliputi: perencanaan, pelaksanaan tindakan, observasi dan evaluasi serta refleksi. Data dalam penelitian ini adalah data kualitatif dan data kuantitatif. Data kualitatif diambil dengan menggunakan lembar observasi, sedangkan data kuantitatif diperoleh melalui tes siklus. Berdasarkan analisis data menunjukan bahwa: 1) aktivitas siswa dengan penerapan model pembelajaran Numbered Head Togeteher pada skor rata-rata aktivitas siswa siklus I sebesar 2,8 yang termasuk pada kategori cukup meningkat pada siklus II menjadi 3,6 yang termasuk padakategori baik; 2) keefektifan mengajar guru ditunjukkan dengan skor rata-rata padasiklus I adalah 2,9 yang termasuk kategori baik dan meningkat lebih efektif lagi pada siklus II menjadi 3,7 yang berkategori baik mengarah ke sangat baik; 3). Terjadi peningkatan hasil belajar siswapada siklus I dari 26 orang siswa hanya 15 orang siswa yang tuntas dengan presentase ketuntasan $62,32 \%$ dengan nilai rata-rata 63,86 . Pada siklus II mengalami peningkatan yaitu dari 26 orang siswa ada 23 orang siswa yang tuntas dengan presentase ketuntasan $90 \%$ dengan nilai ratarata 85,62 .

\section{Kata Kunci: Model, NHT, Hasil Belajar}

ABSTRACT: The main objective in this research is 1) to increase student learning activities on the application of the Numbered Head Together model in Social Studies learning for Class VII MTs.S students Ash-Shiddiq Tikep, 2) to improve the effectiveness of teaching teachers in the application of the Numbered Head Together model in Social Studies learning Students of Class VII MTs.S AshShiddiq Tikep, 3) to improve student learning outcomes through the application of the Numbered Head Together model in social studies learning of Class VII Students of MTs.S Ash-Shiddiq Tikep. This type of research is Classroom Action Research. This research was conducted on March 22 until April 26, 2018 which was seen as many as two cycles and each cycle consisted of two meetings conducted in the even semester of the academic year 2017/2018 for students of class VII MTs.S Ash-Shiddiq Tikep. The procedures of this research include: planning, implementing actions, observing and evaluating as well as reflecting. The data in this study are qualitative data and quantitative data. Qualitative data were collected using observation sheets, while quantitative data were obtained through cycle tests. Based on data analysis shows that: 1) student activities with the application of the Numbered Head Togeteher learning model on the average score of cycle I students activities of 2.8 which included in the category quite increased in cycle II to 3.6 which included in both categories; 2) the teaching effectiveness of teachers is shown by the average score 
E-ISSN: $2502-6674$

P-ISSN: 2502-6666

http://ojs.uho.ac.id/index.php/p_sejarah_uho

on the first cycle is 2.9 which belongs to the good category and increases even more effectively in the second cycle to 3.7 which categorizes good leads to very good; 3). An increase in student learning outcomes in the first cycle of 26 students only 15 students who completed with a percentage of completeness $62.32 \%$ with an average value of 63.86 . In the second cycle, there was an increase, from 26 students there were 23 students who were completed with $90 \%$ completeness with an average value of 85.62 .

\section{Keywords: Model, NHT, Learning Outcomes}

\section{PENDAHULUAN}

Negara berkembang selalu berusaha untuk mengejar ketinggalannya, yaitu dengan giat melakukan pembangunan di segala bidang kehidupan. Dalam bidang pendidikan pemerintah selalu berusaha untuk meningkatkan kualitas pendidikan dengan berbagai cara seperti mengganti kurikulum, meningkatkan kualitas guru melalui penataran-penataran atau melanjutkan sekolah ke tingkat yang lebih tinggi, memberi dana Bantuan Operasional Sekolah (BOS) dan sebagainya. Berdasarkan Pasal 3 UU No. 20 Tahun 2003 tentang Sistem Pendidikan Nasional, menyatakan bahwa: "Pendidikan nasional berfungsi mengembangkan kemampuan dan membentuk watak serta peradaban bangsa yang bermartabat dalam rangka mencerdaskan kehidupan bangsa, bertujuan untuk berkembangnya potensi peserta didik agar menjadi manusia yang bertakwa kepada Tuhan YME, berakhlak mulia, sehat, berilmu, cakap, kreatif, mandiri dan menjadi warga negara yang demokratis serta bertanggung jawab".

Dengan memperhatikan isi dari UU No. 20 Tahun 2003 tersebut, peneliti berpendapat bahwa tugas seorang peneliti memang berat, sebab kemajuan suatu bangsa ditentukan oleh keberhasilan pendidikan dari bangsa itu sendiri. Jika seorang guru atau pendidik tidak berhasil mengembangkan potensi peserta didik maka negara itu tidak akan maju, sebaliknya jika guru atau pendidik berhasil mengembangkan potensi peserta didik, maka terciptalah manusia yang cerdas, terampil, dan berkualitas.

Untuk mencapai tujuan ini peranan guru sangat menentukan. Menurut Wina Sanjaya (2006: 19), peran guru adalah: "Sebagai sumber belajar, fasilitator, pengelola, demonstrator, pembimbing, dan evaluator." Sebagai motivator guru harus mampu membangkitkan motivasi siswa agar aktivitas siswa dalam proses pembelajaran berhasil dengan baik. Hasil belajar merupakan bagian terpenitng dalam pembelajaran. Nana Sudjana (2009: 3) mendefinisikan hasil belajar sisiwa pada hakikatnya adalah perubahan timgkah laku sebagai hasil belajar dalam pengertian yang lebih luas mencangkup bidang kognitif, efektif, dan psikomotorik. Mudjiono (2006: 45) juga menyebutkan hasil belajar merupakan hasil dari suatu interaksi tindak belajar dan tindak mengajar. Dari sisi guru, tindak mengajar diakhiri dengan proses evaluasi hasil belajar. Dari sisi siswa, hasil belajar merupakan berakhirnya pengajaran dari puncak proses belajar.

Salah satu cara untuk membangkitkan aktivitas siswa dalam proses pembelajaran adalah dengan mengganti cara / model pembelajaran yang selama ini tidak diminati lagi oleh siswa, seperti pembelajaran yang dilakukan dengan ceramah dan tanya-jawab, model pembelajaran ini membuat siswa jenuh dan tidak kreatif. Suasana belajar mengajar yang diharapkan adalah menjadikan siswa sebagai subjek yang berupaya menggali sendiri, memecahkan sendiri masalah-masalah dari suatu konsep yang dipelajari, sedangkan guru lebih banyak bertindak sebagai motivator dan fasilitator. Situasi belajar yang diharapkan di sini adalah siswa yang lebih banyak berperan (kreatif).

IPS merupakan integrasi dari berbagai cabang ilmu sisial, seperti sosiologi, ekonomi, polituk, dan budaya. IPS dirumuskan atas dasar realitas dan fenomena sosial yang mewujudkan suatu pendekatan interdispliner dari aspek dan cabang-cabang ilmu sosial. IPS atau studi sosial merupakan bagian dari kurikulum sekolah yang dirumuskan dari isi materi cabang-cabang ilmu ilmu sosial (Triatno, 2010: 171).

Berdasarkan kajian terhadap hasil observasi, diperoleh permasalahan yang menjadi penyebab rendahnya keaktifan belajar siswa kelas VII MTs.S Ash-shiddiq Tikep. Guru menggunakan metode yang kurang bervariasi dan siswa kurang terlibat secara aktif dalam kegiatan pembelajaran. Proses pembelajaran menyebabkan kurangnya keaktifan belajar siswa pada mata 
E-ISSN: $2502-6674$

P-ISSN: 2502-6666

http://ojs.uho.ac.id/index.php/p_sejarah_uho

pelajaran IPS sehingga mengakibatkan siswa cenderung menjadi pasif dalam belajar, kurang menghargai guru, dan kurang memahami materi yang disampaikan.

Terkait dengan mutu pendidikan pada jenjang Sekolah Menengah Pertama (SMP/MTS) sampai saat ini masih jauh dari yang kita harapkan, salah satunya misalnya di MTs.S Ash-shiddiq Tikep. Berdasarkan hasil observasi sebelum melakukan penelitian ini, bahwa hasil belajar IPS kelas VII MTs.S Ash-shiddiq Tikep terbukti menunjukan bahwa dari 26 orang siswa, hanya 16 orang siswa atau sebesar $62,70 \%$ yang mencapai nilai kriteria minimum (KKM) yang ditentukan oleh sekolah yakni 70 .

Metode yang selalu digunakan dan terlalu lama dapat menimbulkan kejenuhan dan kebosanan bagi siswa, sehingga proses pembelajaran tidak berlangsung secara efektif dan tujuan pembelajaran tidak tercapai sebagaimana yang diharapkan. Sesuai dengan tanggapan beberapa siswa tentang metode ceramah yang digunakan guru dalam mengajar, mereka merasa jenuh dan bosan dalam belajar karena guru selalu ceramah dalam menyampaikan materi. Mereka sangat antusias ketika akan diterapkan metode pembelajaran baru dalam kegiatan pembelajaran. Oleh sebab itu, untuk menciptakan proses pembelajaran yang lebih efektif, meningkatkan interaksi yang terjadi pada siswa dan dapat meningkatkan hasil belajar siswa, maka perlu diterapkan metode mengajar yang bervariasi di dalam proses pembelajaran.

Solusi untuk mengatasi permasalahan belajar siswa kelas VII MTs.S Ash-shiddiq Tikep tersebut adalah dengan menerapkan model pembelajaran Numbered Heads Together. Alasan pemilihan model pembelajaran Numbered Head Together karena dengan menggunakan model pembelajaran tersebut, selain dituntut aktif berbicara siswa juga dituntut untuk memaksimalkan pengetahuan dan pemahaman dalam belajar sehingga materi yang dipelajari dapat terselesaikan sesuai dengan tujuan pembelajaran. Berdasarkan Latar belakang masalah yang ada, maka dilakukan penelitian tentang: Penerapan Model Pembelajaran Numbered Head Together (NHT) Sebagai Upaya Meningkatkan Hasil Belajar IPS Siswa Kelas VII MTs.S Ash-Shiddiq Tikep. Penerapan model pembelajaran ini diharapkan siswa yang sebelumnya memiliki nilai yang rendah maka dapat aktif dengan lebih bermakna baik untuk dirinya sendiri, guru, teman maupun lingkungan belajarnya.

\section{METODE PENELITIAN}

Penelitia ini telah dilaksanakan di Kelas VII MTs.S Ash-shiddiq Tikep Kabupaten Muna Barat, Sulawesi Tenggara dengan menggunakan penelitian tindakan kelas (classroom action research), subjek penelitian adalah siswa kelas VII MTs.S Ash-Shiddiq Tikep yang berjumlah 26 orang, yang terdiri dari 13 orang laki-laki dengan 13 orang perempuan. Pengambilan data dilakukan oleh observer yang terdiri dari peneliti sendiri dan observer lain yang memang sengaja diminta oleh peneliti untuk membantu dalam proses pengambilan data. Sebelum masuk pada siklus I dilakukan studi pendahuluan yang berupa identifikasi permasalahan yang disebut dengan pra siklus. Pada tahap ini peneliti melakukan proses pengambilan data menggunakan instrumen lembar observasi untuk mendapatkan data keaktifan belajar siswa yang masih menggunakan metode pembelajaran ceramah dan wawancara dengan guru mata pelajaran serta siswa yang dipilih secara acak dan dianggap mewakili untuk mendapatkan tanggapan terkait proses kegiatan pembelajaran menggunakan metode pembelajaran konvensional atau ceramah yang selama ini digunakan.

Setelah pra siklus dilaksanakan dan didapatkan hasil refleksinya, maka hasil refleksi dari tahap pra siklus tersebut dijadikan pokok permasalahan dalam melaksanakan kegiatan pada siklus I ini. Rincian kegiatan yang akan dilakukan pada siklus ini adalah sebagai perencanaan, pelaksanaan pengamatan, dan melakukan refleksi 
E-ISSN: $2502-6674$

P-ISSN: 2502-6666

http://ojs.uho.ac.id/index.php/p_sejarah_uho

Adapun desain atau rancangan dalam penelitian ini dapat digambarkan sebagai berikut:

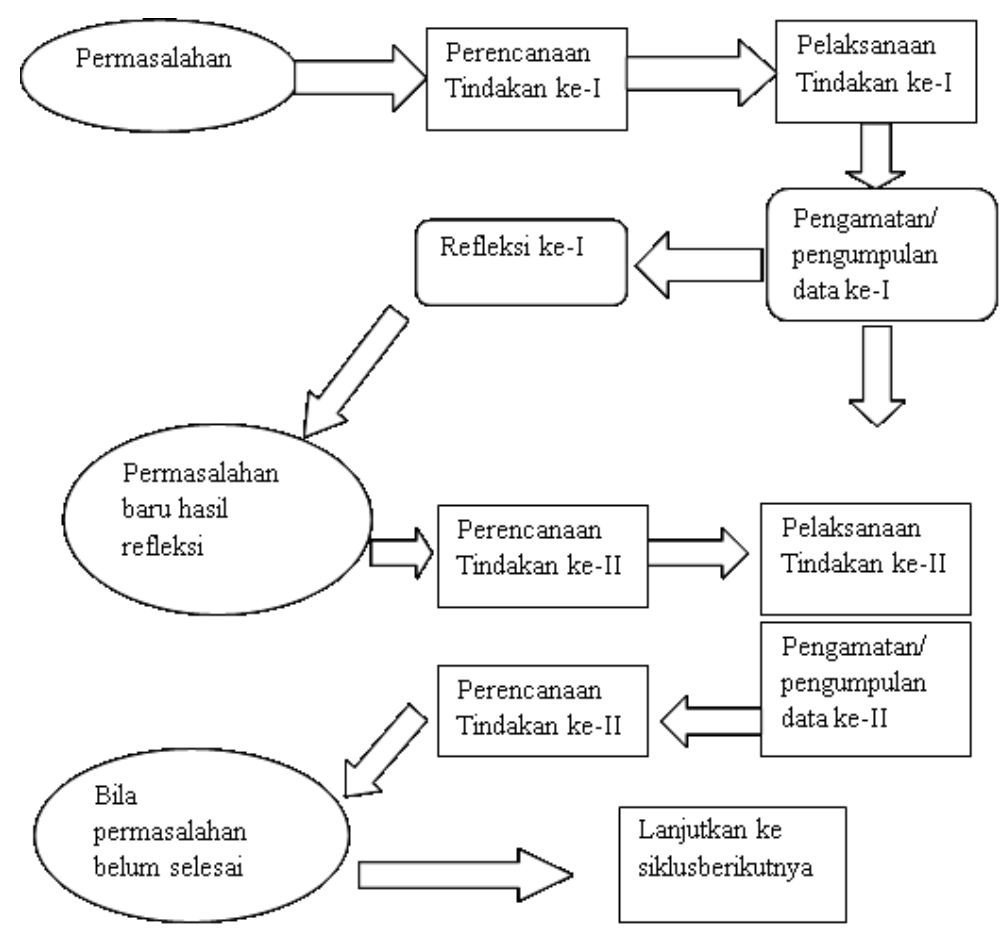

Gambar I. Prosedur Penelitian (Arikunto, 2007: 112)

Teknik pengumpulan data dilakukan dengan cara observasi, dan serta menggunakan tes hasil belajar, data yang diperoleh dialkukan analisis dengan menggunakan statistik deskriptif untuk menghitung nilai siswa, rata-rata nilai siswa, ketuntasan belajar, keberhasilan aktivitas mengajar guru dan keberhasilan aktivitas belajar siswa.

1. Menentukan Nilai Siswa

Nilai siswa ditentukan skor diperoleh siswa pada tes yang dilakukan dengan rumus:

Nilai siswa $=\frac{\text { skor peroleh siswa }}{\text { skor maksimum }} \times 100 \quad($ Suparno, 2008:80)

2. Menentukan Rata-Rata Nilai Siswa

$\bar{x}=\frac{\sum_{\chi \mathrm{i}}}{\eta}$

Keterangan

$\mathrm{n} \quad=$ Jumlah siswa secara keseluruhan

$\bar{x} \quad=$ Nilai rerata yang diperoleh

$\sum_{\chi \mathrm{i}}=$ Jumlah nilai setiap siswa

3. Menentukan ketuntasan belajar siswa

a. Ketuntasan Individu

Ketuntasan individu siswa ditentukan berdsarkan nilai yang diperoleh pada setiap siklus. Siswa dikatakan tuntas jika nilai diperoleh siswa adalah $\geq$ sesuai KKM yang ditetapkan oleh sekolah.

b. Ketuntasan klasikal

Ketentuan klasikal ditentukan berdasarkan presentase ketuntasan individu siswa pada setiap siklus pembelajaran dengan rumus sebagai berikut:

$\%$ tuntas $=\frac{\sum \mathrm{f}_{\mathrm{i}}}{\eta}$

Keterangan

$\mathrm{n}=$ Jumlah siswa secara keseluruhan

$\sum \mathrm{f}_{\mathrm{i}}=$ Jumlah siswa pada kategori ketuntasan belajar

Ketuntasan klasikal tercapai jika 80\% siswa mencapai KKM yaitu 
E-ISSN: $2502-6674$

P-ISSN: 2502-6666

http://ojs.uho.ac.id/index.php/p_sejarah_uho

70 ang ditetapkan oleh sekolah.

1. Menentukan Keberhasilan Efektivitas Mengajar Guru

Untuk menentukan keberhasilan efektivitas mengajar guru dapat dilihat pada pelaksanaan skenario pembelajaran. Presentase keterlaksanaan pembelajaran dihitung berdasarkan jumlah skor guru dengan jumlah skor maksimum dikalikan seratus persen.

$\% \mathrm{KEMG}=\frac{\mathrm{JSPG}}{\mathrm{JSMG}} \times 100 \% \quad$ (Suparno, $\left.2008: 81\right)$

Dengan:

JSPG $=$ Jumlah skor perolehan guru dalam pelaksanaan skenario pembelajaran.

$\mathrm{JSMG}=$ Jumlah skor maksimum skenario pembelajaran.

2. Menentukan Keberhasilan Aktivitas Belajar Siswa

Keberhasilan pemeblajaran sisiwa dihitung berdasarkan skor perolehan siswa kemudian dibagi dengan jumlah skor maksimum dikalikan dengan seratus persen.

$\% \mathrm{KABS}=\frac{\mathrm{JSPS}}{\mathrm{JSMS}} \times 100 \%$

Dengan:

JSPS $=$ Jumlah skor perolehan siswa dalam mengikuti proses pembelajaran

JSMS = Jumlah skor maksimum siswa dalam proses pembelajaran.

\section{HASIL PENELITIAN DAN PEMBAHASAN}

\section{A. Hasil Penelitian}

\section{Pelaksanaan Siklus I}

Kegiatan penelitian ini diawali dengan kegiatan pendahuluan yakni dengan menyaipkan seluruh perangkat pembelajaran, setelah semua perlengkapan selesai makan dilakukan pelaksaaan tindakan untuk siklus pertama yang dimulai dari kegiatan perencanaan dan diakhiri dengan refleksi hasil kegiatan.

Berdasarkan hasil obserbvasi pelaksanaan tindakan siklus I adalah cara guru menyajikan materi pelajaran apakah hasil sudah sesuai dengan skenario pembelajaran yang telah dibuat atau belum. Selain dari observasi efektivitas mengajar guru dan aktivitas belajar siswa masing-masing mencapai persentase $65 \%$ dan $50 \%$ terlaksananya skenario pembelajaran.dari temuan tersebut dapat dilihat bahwa aktivitas belajar siswa pada siklus I belum mencapai maksimal hal ini disebabkan siswa masih baru menggunakan model pembelajaran ini, siswa tidak aktif dalam diskusi kelompok, siswa masih malu-malu mempresentasekan kelompoknya. Sedangkan aktivitas bmengajar guru juga belum selesai dengan baik hal ini disebabkan karena guru belum mampu menkondisikan waktu mengajar, guru tidak dapat mendampingi siswanya dengan baik

Setelah pelaksanaan tindakan siklus I selama 2 kali pertemuan diadakan evaluasi. Dari tes siklus I diperoleh rata-rata nilai siswa sebesar 70,35\% dengan presentase ketuntasan klasikal hanya mencapai $62,32 \%$ atau hanya 15 orang yang tuntas dari 26 orang siswa. Karena belum mencapai indikator keberhasilan maka penelitian dilanjutkan pada siklus II.

\begin{tabular}{llcc}
\hline No & Kriteria Ketuntasan & Jumlah Siswa & Presentase \\
1 & Tuntas & 15 & $62,32 \%$ \\
2 & Tidak Tuntas & 11 & $38,68 \%$ \\
& Jumlah & 26 & \multicolumn{2}{c}{$100 \%$} \\
\hline
\end{tabular}

(Sumber: Diolah dari hasil penelitian)

Dari hasil observasi dan evaluasi, pelaksanaan tindakan siklus I belum mencapai indikator keberhasilan yang telah ditetapkan. Hal ini menunjukan bahwa penerapan model pembelajaran NHT masih belum sempurna. Pada tahap ini peneliti bersama guru menilai dan mendiskusikan kelemahan dan kekurangan yang terdapat pada tindakan siklus I, untuk kemudian diperbaiki dan dilaksanakan untuk tindakan siklus II. Berdasarkan hasil observasi peneliti menilai banyak kekurangan yang dilakukan guru anatara lain: (1) Dalam proses belajar mengajar, guru kurang tegas dan kurang memotivasi siswa, (2) Guru tidak menyampaikan indikator dan tujuan pembelajaran siswa, (3) Guru kurang membimbing siswa yang mengalami kesulitan, (4) Guru 
E-ISSN: $2502-6674$

P-ISSN: 2502-6666

http://ojs.uho.ac.id/index.php/p_sejarah_uho

kurang memantau jalannya diskusi. Adapun dari factor siswa yaitu: (1) Dalam pembelajaran siklus 1 ini sebagian siswa belum tertarik dengan penerapan model pembelajaran Numbered Head Together dikarenakan guru belum memotivasi. (2) Sebagian siswa kuruang aktif dalam kegiatan inti pembelajaran dan dalam menyimpulkan materi. (3) Siswa kurang memehami tujuan dari pembelajaran pada siklus 1 dikarenakan guru tidak menyampakan tujuan pembelajaran. Pada tindakan siklus I ini penerapan model pembelajaran NHT dalam mengajarkan pokok materi Kehidupan Masyarakat Pada Masa Hindu Budha dan Kerajaan-kerajaan Hindu Budha di Indonesia, belum sempurna sesuai dengan yang diharapkan.

Analisis terhadap observasi dijadikan sebagai bahan untuk menentukan tindakan selanjutnya. Setelah diadakan refleksi anatara observer dan peneliti maka pada pertemuan selanjutnya guru harus: memberi motivasi dan apersepsi kepada siswa sebelum memulai proses pembelajaran., Memberi bimbingan kepada setiap kelompok yang mengalami kesulitan, mampu mengelola waktu dengan efisien agar semua tahapan kegiatan dalam skenario pembelajaran dapat terlaksana.

\section{Pelaksanaan Tindakan Siklus II}

Setelah pelaksanaan siklus I belum berhasil dan masih banyak kekurangan maka kegiatan penelitian dilanjutkan kesiklus kedua. Sebagaimana siklus I dalam siklus II juga dilakukan persiapan yang dimulai dari kegiatan pendahuluan hingga kegiatan akhir dalam pembelajaran. Berdasarkan hasil observasi selama kegiatan pembelajaran ditemukan aktivitas belajar siswa presentase $90 \%$ dan efektivitas mengajar guru mencapai $85,12 \%$ yang menentukan terlaksananya skenario pembelajaran.

Setelah pelaksanaan tindakan siklus II selama 2 kali pertemuan diadakan evaluasi dengn tes . Hasil tes siklus II menunjukan bahwa terjadi peningkaan jika dibandingkan dengan hasil tes siklus I yaitu $62,32 \%$ ( 15 orang) siswa memperoleh nilai $\geq 70$ pada tes siklus I dan meningkat menjadi $90 \%$ (23 orang) siswa memperoleh nilai $\geq 70$ pada tes siklus II. Karena telah mencapai indiktor keberhasilan maka penelitian ini dihentikan sampai siklus II.

\begin{tabular}{llll}
\hline No & Kriteria Ketuntasan & Jumlah Siswa & Presentase \\
1 & Tuntas & 23 & $90 \%$ \\
2 & Tidak Tuntas & 3 & $10 \%$ \\
& Jumlah & 26 & $100 \%$ \\
\hline
\end{tabular}

(Sumber: Diolah dari hasil penelitian)

Kegiatan refleksi yang dilkukan pada tindakan siklus II menunjukan hasil yang cukup menggembirakan bagi peneliti. Hasil observasi yang dilakukan oleh peneliti menunjukan bahwa pembelajaran dengan menggunakan model pembelajaran NHT sudah mendapatkan hasil yang lebih baik. Jika dilihat dari hasil tes pada evaluasi pelaksanaan tindakan siklus II, yaitu telah mencapai $90 \%$ (23 orang) siswa yang telah memperoleh nilai $\geq 70$ atau dengan kata lain telah mencapai indikator keberhasilan, maka penelitian ini telah berhasil dilaksanakan sesuai rencana pelaksanaan penelitian dengan dua siklus tindakan.

\section{B. Pembahasan Hasil Penelitian}

Pada siklus I, perolehan nilai siswa berdasarkan ketuntasan belajar hanya 62,32\% (15 orang) siswa telah memperoleh nilai $\geq 70$ dengan rata-rata sebesar 70,35 . Berdasarkan hasil observasi pada siklus I, guru dan siswa telah melakukan kegiatan pembelajaran yang sesuai dengan menerapkan model pembelajaran NHT dengan persentase pelaksanaan proses masing-masing $65 \%$ (keefektivan guru) dan 50\% (aktivitas siswa), walaupun masih terdapat kekurangan-kekurangan dimana kekurangan itu ada yang berasal dari guru ada juga yang berasal dari siswa. Diantaranya da sebagian siswa yang tidak memperhatikan penjelasan pada saat menyampaikan materi, dan kekurangan yang berasal dari guru adalah belum terlaksananya semua komponen dalam skenario pembelajaran. Hal itu dikarenakan guru belum dapat mengatur waktu sebaik mungkin, guru terlalu banyak memberikan waktu kepada siswa untuk bekerja menyelesaikan soal-soal yang diberikan, 
E-ISSN: $2502-6674$

P-ISSN: 2502-6666

http://ojs.uho.ac.id/index.php/p_sejarah_uho

dan guru merasa canggung dalam mengajar karena kehadiran peneliti. Selain itu pula guru belum dapat melakukan pembagian kelompok yang tepat masih terkesan homogen, dan pada langkah pemanggilan nomor anggota siswa masih belum antusias dan memberikan tanggapan pada kelompok lain, serta guru belum memberikan penghargaan pada kelompok.

Melihat kekurangan yang masih ada serta hasil belajar IPS pada siswa terhadap pokok bahasan Kehidupan Masyarakat Pada Masa Hindu Budha di Indonesia pada tindakan siklus I belum memenuhi indikator keberhasilan yang telah ditetapkan, maka penelitian dilnjutkan pada tindakan siklus II dengan materi Kerajaan-Kerajaan Hindu Budha di Indonesia adalah guru harus bersikap tegas dengan mengur/ memberi sanksi kepada siswa yang tidak memperhatikan penjelasan guru dan yang tidak mau bekerja sama dengan teman kelompoknya. Guru juga harus mampu mengelola waktu dengan efisien agar semua tahapan kegiatan dalam skenario pembelajaran dapat terlaksana.

Pada tindakan siklus II, model pembelajaran NHT kembali dilaksanakan. Berdasarkan hasil observasi pada tindakan siklus II, kegiatan guru dalam mlaksanakan proses pembelajaran telah meningkat dengan presentase pelaksanaan proses telah mencapai $90 \%$ dan presentase aktivitas siswa mencapai $85,12 \%$. Dimana kekurangan-kekurangan yang terjadi pada siklus II sudah dapat diperbaiki. Guru sudah memberi motivasi dan apersepsi kepada siswa sebelum memulai proses pembelajaran, serta guru telah melaksanakan bimbingan kepada setiap kelompok yang mengalami kesulitan. Berdasarkan hasil evaluasi yang dilakukan pada siklus II siswa yang memperoleh nilai $\geq$ 70 sebanyak 23 orang atau 90\% ini berarti mengalami peningkatan. Hal ini berarti telah mencapai indikator yang telah ditetapkan. Karena indikator keberhasilan dalam penelitian ini telah tercapai, ini berarti proses tindakan telah tercapai yaitu dengan merupakan model pembelajaran NHT hasil belajar IPS pada siswa kelas VII MTs.S Ash-Shiddiq Tikep kabupaten Muna Barat dapat ditingkatkan.

\section{PENUTUP}

Berdasarkan penelitian tindakan kelas yang telah dilakukan terlihat adanya perubahan yang merupakan hasil penelitian dalam rangka usaha meningkatkan hasil belajar. Berdasarkan tindakan yang dilaksanakan pada penelitian ini, maka dapat memberikan beberapa kesimpulan sebagai berikut: pertama penerapan model pembelajaran NHT dalam pembelajaran IPS dapat meningkatkan efektivitas mengajar guru kelas VII MTs.S Ash-Shiddiq Tikep dimana pada siklus I hanya mencapai $65 \%$ dan pada siklus II meningkat menjadi $90 \%$. Kedua penerapan model pembelajaran NHT dalam pembelajaran IPS dapat meningkatkan aktivitas belajar siswa kelas VII MTs.S Ash-Shiddiq Tikep dimana pada siklus I hanya mencapai $50 \%$ dan siklus II mengalami peningkatan mencapai $85,23 \%$. Ketiga dari segi hasil belajar yang diperoleh siswa pada siklus I secara klasikal ketuntasan mencapai $62,23 \%$ dengan nilai rata-rata 70,35 sedangkan pada siklus II mengalami peningkatan menjadi $90 \%$ dengan nilai rata-rata 80,35 .

\section{DAFTAR PUSTAKA}

Arikunto, Suharsiwi. 2007. Penelitian Tindakan Kelas. Jakarta: Bumi Aksara.

Dahar. 2011. Teori Belajar Bermakna. Jakarta: Rineka Cipta.

Dimyati dan Mudjiono,2002. Belajar dan Pembelajaran. Jakarta: Rineka Cipta.

Ekawarna, 2010. Penelitian Tindakan Kelas. Jakarta: Gaung Persada Press.

Hamalik, Oemar. 2003. Proses Belajar Mengajar. Jakarta: Bumi Aksara.

Iskandar. 2008. Metodologi Penelitian Pendidikan dan Sosial. Jakarta: Gaung Persada Press.

John Dewey. 2001. Pengalaman dan Pendidikan. Jakarta: Kepel Press.

Morisan. 2012. Metode Penelitian Survei. Jakarta: Kharisma Putra Utama.

Rianse Usman dan Abdi. 2008. Metodologi Penelitian Sosial dan Ekonomi. Bandung: Alfabeta. 